\title{
Chemotaxonomy and cytotoxicity of the liverwort Porella Viridissima
}

\author{
Métoyer Benjamin 1, 2, Lebouvier Nicolas ${ }^{1}$, Hnawia Edouard ${ }^{1}$, Thouvenot Louis ${ }^{3}$, Wang Fengrui 4 , \\ Harinantenaina Rakotondraibe Liva ${ }^{4}$, Raharivelomanana Phila ${ }^{5}$, Asakawa Yoshinori ${ }^{2}$,
}

Nour Mohammed ${ }^{1}{ }^{*}$

${ }^{1}$ Institut des Sciences Exactes et Appliquées (ISEA)-EA 4243, Université de la Nouvelle-Calédonie, Nouméa Cedex, Nouvelle-Calédonie, France

${ }^{2}$ Faculty of Pharmaceutical Sciences, Tokushima Bunri University, Tokushima, Japan

${ }^{3}$ Independant Researcher, Pergignan, France

4 Division of Medicinal Chemistry and Pharmacognosy, College of Pharmacy, The Ohio State University, Columbus, OH, USA

${ }^{5}$ Ecosystèmes Insulaires Océaniens (UMR EIO 241), University of French Polynesia, Faaa, French

Polynesia

* Corresponding author : Mohammed Nour, email address : mohammed.nour@univ-nc.nc

\begin{abstract}
:
The first chemotaxonomic study based on volatile components of Porella viridissima (Mitt.) Grolle is reported. The GC-MS analysis of ether extract was performed; ten santalane and five pinguisane-type sesquiterpenes were identified together with perrottetianal $A$ as major diterpene. Most of detected santalane-type sesquiterpenes are reported for the first time in liverwort. P. viridissima was found to belong to the chemotype III (pinguisane/sacculatane) and shared chemical similarities with P. navicularis. Perrotettianal A was isolated and has shown strong cytotoxicity against ovarian cancer.
\end{abstract}

\section{Graphical abstract}

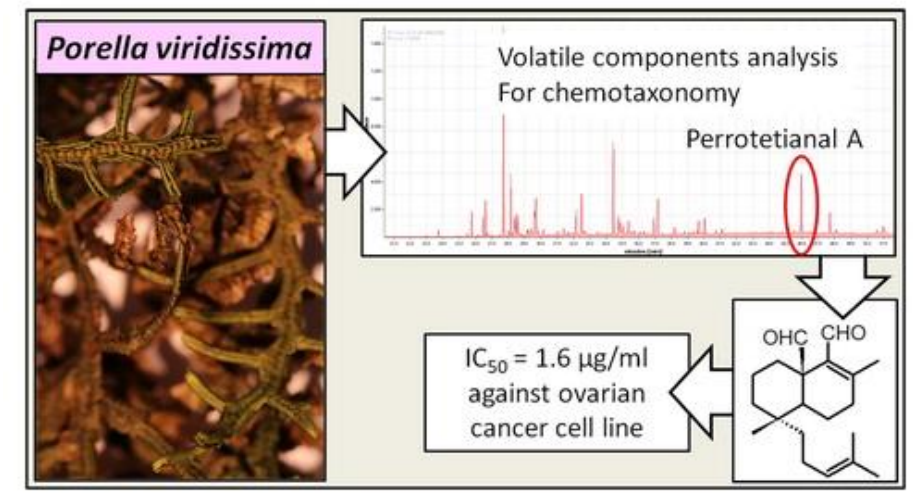


Keywords : Liverwort, Porella viridissima, chemotype, pinguisane, sacculatane, ovarian cancer 


\section{Experimental}

\section{General}

Plant material was air-dried at room temperature and small amount of sample was crushed and extracted with diethyl ether with mortar and pestle. Extract was then purified through a Pasteur pipette packed with silica gel using diethyl ether as eluent to retrieve polar compounds.

Crude extract has been analyzed by GC-FID-MS. GC-FID-MS analysis was performed using a gas chromatograph coupled with a mass detector (Clarus ${ }^{\circledR}$ 580, Perkin Elmer Inc, Waltham, MA, USA) and a flame ionization detector (Clarus® 580, Perkin Elmer Inc, Waltham, MA, USA) using helium at $1 \mathrm{ml} / \mathrm{min}$. Capillary column was a elite-5MS $(30 \mathrm{~m} \times 0.25 \mathrm{~mm}, 0.25$ $\mu \mathrm{m})$ (Perkin Elmer Inc, Akron, OH, USA). Analysis was performed using EI mode. The injection temperature was set at $250^{\circ} \mathrm{C}$. Analyses were carried out using a temperature program starting from $50^{\circ} \mathrm{C}$, with an initial $3 \mathrm{~min}$ hold, to $250^{\circ} \mathrm{C}$ with a $5^{\circ} \mathrm{C} / \mathrm{min}$ heating ramp, and keeping the final temperature stable for $15 \mathrm{~min}$. Mass range was set at $\mathrm{m} / \mathrm{z} 40-500$. The individual peaks were identified by comparison of mass spectra from libraries as well as the Van den Dool and Kratz indices (LRI), which were calculated for all volatile constituents using a homologous series of n-alkanes C8-C32 (van Den Dool \& Dec. Kratz 1963; Zellner et al. 2008) and were compared with available literature data. Mass Finder 2.3 library, NIST library (Gaithersburg, MD, USA), Wiley library (Hoboken, NJ, USA) were used for mass spectra comparison and identification. We used mainly NIST MS Search 2.2 software, Pherobase (The Pherobase: Database of pheromones and semiochemicals) and literature data (Pripdeevech et al. 2010; Babushok et al. 2011; Ali et al. 2013) for retention index comparison to identify constituents of the crude extracts. Relative percentages of constituents were calculated with the area from the FID corrected with the number of carbon of the corresponding compound (based on the MS identification). NMR analyses were performed on a Varian $(500 \mathrm{MHz})$.

\section{Plant material}

Specimen of Porella viridissima (MET035) was collected in September 2014 in Tontouta, South Province, New Caledonia (Authorization collect number: Arrêté $\mathrm{n}^{\circ}$ 20502014/ARR/DENV). A voucher specimen is deposited at the Institut pour la Recherche et le 
Developpement, Noumea (NOU).

\section{Extraction and Isolation}

Plant material of Porella viridissima $(1 \mathrm{~kg}$ ) was extracted by maceration with diethyl ether (during one week performed three times). The obtained crude extract (13 g) was fractionated on chromatographic open columns using silica gel and a mixture of cyclohexane with ethyl acetate or dichloromethane for elution and using sephadex with methanol as eluent to yield to perrottetianal A ((16), $1.7 \mathrm{~g}, 13.1 \%)$ whose NMR shifts were corroborated with literature (Asakawa et al. 1979).

\section{Cytotoxicity}

Cytotoxicity assays were performed using method published in Nature Protocols (Vichai \& Kanyawim 2006) with slight modification. The A2780 cell line is a drug-sensitive ovarian cancer cell line (Ren et al. 2011). Paclitaxel was used as the positive control and it had an $\mathrm{IC}_{50}$ value of $0.002 \mu \mathrm{M}$.

\section{References}

Ali S, Zhang C, Mohamed A, El-Baz F, Hegazy A, Kord M, Nair M. 2013. Major constituents of Boswellia carteri resin exhibit cyclooxygenase enzyme inhibition and antiproliferative activity. Nat Prod Commun. 8:1365-1366.

Asakawa Y, Toyota M, Takemoto T. 1979. New diterpenes from Porella perrottetiana. Phytochemistry. 18:1681-1685.

Babushok VI, Linstrom PJ, Zenkevich IG. 2011. Retention indices for frequently reported compounds of plant essential oils. J Phys Chem Ref Data. 40:043101.

van Den Dool H, Dec. Kratz P. 1963. A generalization of the retention index system including linear temperature programmed gas-liquid partition chromatography. J Chromatogr A. $11: 463-471$.

Pripdeevech P, Chumpolsri W, Suttiarporn P, Wongpornchai S. 2010. The chemical composition and antioxidant activities of basil from Thailand using retention indices and comprehensive two-dimensional gas chromatography. J Serbian Chem Soc. 75:1503-1513.

Ren Y, Matthew S, Lantvit DD, Ninh TN, Chai H, Fuchs JR, Soejarto DD, de Blanco EJC, Swanson SM, Kinghorn AD. 2011. Cytotoxic and NF- $\kappa B$ Inhibitory Constituents of the Stems of Cratoxylum cochinchinense and Their Semisynthetic Analogues. J Nat Prod. 74:11171125.

The Pherobase: Database of pheromones and semiochemicals. [cited 2017 Sep 29]. Available from: http://www.pherobase.com/ 
Vichai V, Kanyawim K. 2006. Sulforhodamine B colorimetric assay for cytotoxicity screening. Nat Protoc. 1:1112-1116.

Zellner B d'Acampora, Bicchi C, Dugo P, Rubiolo P, Dugo G, Mondello L. 2008. Linear retention indices in gas chromatographic analysis: a review. Flavour Fragr J. 23:297-314.

Table S1. Volatile compounds detected in P. viridissima

\begin{tabular}{|c|c|c|c|}
\hline Attribution & $\mathrm{LRI}_{\text {litt. }}$ & $\mathrm{LRI}_{\text {exp. }}$ & Rel. \% \\
\hline tricycloekasantalal (5) & 1343 & 1349 & 1.0 \\
\hline dehydrotricyclo-eka-santalal (6) & - & 1391 & 0.2 \\
\hline$\alpha$-santalene (1) & 1421 & 1418 & 0.6 \\
\hline epi- $\beta$-santalene $(\mathbf{8})$ & 1424 & 1429 & 3.5 \\
\hline$\alpha$-pinguisene (11) & 1444 & 1459 & 2.8 \\
\hline$\beta$-pinguisene (12) & - & 1500 & 0.4 \\
\hline$\alpha$-photosantalol (4) & 1520 & 1530 & 7.6 \\
\hline (E)- $\alpha$-santalol (3) & - & 1596 & 8.1 \\
\hline$\alpha$-pinguisenol (13) & $*$ & 1616 & 1.1 \\
\hline (Z)- $\alpha$-santalol (2) & 1647 & 1657 & 0.8 \\
\hline (E)-epi- $\beta$-santalol (10) & 1669 & 1673 & 1.1 \\
\hline (Z)-epi- $\beta$-santalol (9) & 1703 & 1708 & 3.8 \\
\hline$(Z)-\beta$-santalol (7) & 1716 & 1723 & 11.0 \\
\hline bryopterin A (14) & - & 1818 & 11.2 \\
\hline neophytadiene I & 1841 & 1839 & 1.5 \\
\hline neophytadiene II & 1866 & 1880 & 3.1 \\
\hline norpinguisone methyl ester (15) & $*$ & 2012 & 1.4 \\
\hline perrottetianal A (16) & $*$ & 2441 & 13.5 \\
\hline Total identified & & & 72.8 \\
\hline Total unidentified & & & 27.2 \\
\hline
\end{tabular}

$\mathrm{LRI}_{\text {exp. }}$ : experimental linear retention indices for $5 \mathrm{MS}$ column, $\mathrm{LRI}_{\text {litt. }}$ : linear retention indices for 5MS column in litterature, * identical to standard : compound isolated and characterized, Rel. \%: relative percentages, -: No LRI literature data for these compounds regarding 5-MS column 